\title{
From Spain to New Spain: Revisiting the Potestas Populi in Hispanic Political Thought*
}

Mónica Quijada

Instituto de Historia

Consejo Superior de Investigaciones Científicas, Madrid

This work studies the configuration in Hispanic political thought of the principle that true political legitimacy is based on the consent of the community and on the contractual nature of the origin of political power. The goal is to recover viewpoints that have been obscured by a Hispanist historiography, that is, a historiography of those whose work on the Hispanic world, which has focused on some authors and excluded others who were as significant and as influential. Moreover, this work seeks to highlight the unique aspects of that tradition in light of how historiography classifies diverse expressions of modern political thought in relation to their conservative or radical potential which, in the end, foreshadow their relation with, and influence on, the political changes of modernity. This article argues that the development of the principle of potestas populi within Hispanic political thought forms part of the long tradition of "radical ideas" that nourished modern revolutions and that this tradition was taken even further when it was applied to-the then recently discovered, that is, conquered-American populations. Finally, this work maintains that political thought should be reconsidered from a viewpoint that is not focused on a world of readers and academic learning-in which ideas, references, and texts are passed among individuals or groups of individuals - but on a more flexible notion and a wider scope: the concept of imaginaire, that is, how societies represent and perceive themselves. The reality of imaginaires resides in their very existence, their impact on mentality and behaviour, and in their capacity to influence decision-making processes.

En este trabajo se estudia la configuración, en el pensamiento político hispánico, del principio según el cual toda legitimidad política se basa en el consentimiento de la comunidad y en la naturaleza contractual del origen del poder. Uno de sus

"This article is part of the Project I+D HUM2006-10136 "Science and Politics Confronting Human Populations" funded by the Ministy of Education and Science, Spain.

Mexican Studies/Estudios Mexicanos Vol. 24, Issue 2, Summer 2008, pages 185-219. IsSN 0742-9797 electronic ISSN 1533-8320. (1)2008 by The Regents of the University of California All rights reserved. Please direct all requests for permission to photocopy or reproduce article content through the Unversity of California Press's Rights and Permissions website, at http://www. ucpressjournals.com/repript (for 
objetivos es recuperar planteamientos que han sido oscurecidos por la excluyente atención que la historiografía interesada en los procesos hispánicos ha prestado a algunos autores, por encima de otros igualmente significativos $e$ influyentes. Se trata además de resaltar los singulares matices de dicha tradición textual, a la luz de la clasificación que la historiografia suele asignar a las distintas expresiones del pensamiento político moderno en función de su potencial conservador o radical; lo que, en última instancia, prefigura sus relaciones e influencias sobre los cambios políticos de la modernidad. Se sostiene aquí que el desarrollo del principio de la potestas populi en el pensamiento político hispánico forma parte de la larga tradición de "ideas radicales" que alimentaron las revoluciones moder nas, que fueron incluso llevadas a extremos no corrientes en la época al ser aplicadas a las poblaciones que habian sido recientemente descubiertas y que eran por tanto poblaciones de conquista. Finalmente, este trabajo mantiene que el pensamiento político debe ser reconsiderado desde una perspectiva que no se centre en un mundo de lectores y conocimiento académico en que ideas, referencias y textos son transmitidos entre individuos o grupos de individuos, sino a partir de una noción más flexible amplia: el concepto de imaginario, es decir el conjunto de representaciones que las sociedades producen y desde las cuales se perciben a sí mismas; y cuya realidad reside en su propia existencia, en su impacto sobre las mentalidades y comportamientos y en su capacidad de influir sobre la toma de decisiones.

Key words: Popular Sovereignty, Contractual Origin of Political Power, Atlantic Revolutions, Spain, New Spain, Salamanca School, Modern Political Thought, Political Imaginaires, Representations

Palabras clave: soberanía popular, origen contractual del poder político, revoluciones atlánticas, España, Nueva España, Escuela de Salamanca, pensamiento político moderno, imaginarios, representaciones.

The age of the Great Atlantic Revolutions was characterized in the Hispanic $^{1}$ world by a series of profound transformations. The Napoleonic invasion of Spain in 1808, the removal of King Fernando VII, and the imposition of Joseph Bonaparte as ruler of the Spanish Monarchy created a power vacuum that ultimately resulted in the emergence of a liberal order in the Hispanic world. ${ }^{2}$ Although those in power accepted the

1. In this work the term Hispanic is used in its broadest sense to include all the lands that, during the Modern Period-also known as the Early Modern Period in the English speaking world-were politically associated with the Spanish Monarchy both in Europe and in America.

2. The term liberal, in its current political meaning, had its origin in Spain and it would later be adopted by the English political lexicon. change, the people did not. In rejecting the invaders, they restored, revitalized, and/or redefined political institutions, such as juntas (governing committees) and ayuntamientos (city governments). They also convened a cortes (parliament) at Cádiz that promulgated the Constitution of 1812. Moreover, autonomous movements emerged in America that ultimately led to independence and the creation of new nation states. These events were preceded by a period of enlightened despotism fostered by a new dynasty - the Bourbons-who introduced new political institutions and practices that, malgré their intentions, generated foreseen and un foreseen, albeit uncontrollable, processes of action and reaction.

Thousands of documents, texts, speeches, pamphlets, sermons, catechisms, constitutional debates, and other forms of communication and collective distribution of ideas and political processes were disseminated among a large number of social groups throughout the Hispanic world after 1808. Concepts such as el pueblo (the people), soberanía (sovereignty), retroversión de la soberanía (retroversion of sovereignty), and derecho de resistencia (the right of resistance) systematically appear and reappear in these sources. No one today doubts the potential of these concepts as ideological tools utilized in the political changes of the period. What is still debated, in the case of the Hispanic world, is whether or not the assumption of these notions resulted from the influence of the two great revolutions at the end of the eighteenth century, the U.S. and the French revolutions; the revitalization of natural law among enlightened thinkers-stemming from either Francisco Suárez's NeoScholastic thought, from prestigious and renovating texts such as those written by Samuel Pufendorf or Emmerich de Vatel, or from the flowering of a Hispanic political culture that formed over a long period.

This is neither a mere academic debate nor a frivolous discussion as some historians, who believe that ideas are of secondary importance in historical processes, have asserted. They are not. It is through ideas that the relations in our current societies play themselves out using a fundamental principle of the democratic system of political coexistence: the principle that popular sovereignty is the only legitimate source of power.

This discussion is not being conducted in a historiographical void. In the last decades, historiography has made notable progress in recovering and validating the political processes in the Hispanic world within the context of the Atlantic Revolutions, for example, the debates at the Cortes of Cádiz and the constitutional text derived from such debates, as well as the ideas and practices that expanded after 1808 in the Peninsula and in America. ${ }^{3}$ To understand the current discourse, I have reex-

3. Two seminal works in this historiographical renovation are: François-Xavier Guerra, Modernidad e Independencias (Madrid: Colecciones Mapfre, 1992), and Jaime E. 
amined past interpretations, many of them concerned with specific topics, regarding the scope and specificity of liberal principles and practices in Spanish America.

One issue-the discovery of the expansion, after 1808, of electoral processes of great breadth and scope, which had not been taken into consideration until recently-has contributed significantly to modifying traditional views about "the political" in the Hispanic context. ${ }^{5}$ Today

Rodríguez O., La Independencia de la América Española (Mexico: Fondo de Cultura Económica, 1996) (and the revised and expanded English edition: The Independence of Spanish America, (Cambridge-New York: Cambridge University Press, 1998).

4. See, for example, among others Antonio Annino, "El paradigma y la disputa. La cuestión liberal en México y en la América hispana," in Francisco Colom (ed.), Relatos de Nación. La construcción de las identidades nacionales en el mundo hispánico (Madrid Iberoamericana, 2006), 103-130; Jordana Dym, From Sovereign Villages to National States. City, State, and Federation in Central America, 1759-1839 (Alburquerque: University of Nuevo Mexico Press, 2006); Marta Irurozqui, La Mirada esquiva. Reflexiones bistóricas sobre la interacción del estado y la ciudadanía en los Andes (Bolivia, Ecuador; y Perú), siglo XIX (Madrid, CSIC, 2005); Jaime E. Rodríguez O. (ed.), The Divine Charter Constitutionalism and Jiberalism in Nineteenth Century Mexico, (Lanhan: Rowman and Littlefield Publishers, Inc., 2005)

5. There exists an ample bibliography with regards to voting in nineteenth-century Hispanic America. The following are some representative titles, which ought to begin with the pioneering works of Nettie Lee Benson, "The Contested Mexican Election of 1812", Hispanic American Historical Review 26:3, (August 1946), 336-50 and La Diputación provincial y el federalismo mexicano (México: El Colegio de México, 1955). The following articles from scholarly compilations are important: Antonio Annino (coord.), Historia de las Elecciones en Iberoamérica (Buenos Aires: Siglo XXI, 1995); Carlos Malatmud (ed.), Legitimidad, representación y alternancia en Europa y América Latina: las reformas electorales, 1880-1930 (México: Fondo de Cultura Económica and El Colegio de México, 2000); Eduardo Posada-Carbó (ed.), Elections before Democracy. The History of Election. in Europe and Latin America (London: Institute of Latin American Studies Series, 1996) Hilda Sabato (coord.), Ciudadanía politica y formación de las naciones. Perspectivas bistóricas en América Latina, (México: Fondo de Cultura Económica, 1999). Among individual works, it is crucial to cite: Virginia Guedea: "Las primeras elecciones populares en la ciudad de México, 1812-1813", Mexican Studies/Estudios Mexicanos 7:1, (Winter 1991), 1-28; Francois-Xavier Guerra, "El soberano y su reino. Reflexiones sobre la génesis del ciudadano en América Latina", in Hilda Sabato (ed.), Ciudadanía política, pp. 3361; Marta Irurozqui: A bala, piedra y palo. La construcción de la ciudadanía política en Bolivia, 1826-1952 (Sevilla: Diputación de Sevilla, 2000); Victor Peralta, "Elecciones, constitucionalismo y revolución en eJ Cuzco, 1809-1815”, Revista de Indias 56:206, (1996), 99-131; Jaime E. Rodríguez O., "Las primeras elecciones constitucionales en el Reino de Quito 1809-1814 1821-1822" in Procesos. Revista Ecuatoriana de Historia 14 (1999), Quito, 1808-1822, (Quito: Universidad Andina Simón Bolívar-Corporación Editora Nacional, 2006). For a complete bibliography regarding this topic, see Marta Irurozqui: La ciudadanía en debate en América. Latina. Discusiones bistoriográficas y una propuesta teórica sobre el valor público de la infracción electoral. Documento de Trabajo No.I 139, IEP (Lima: Instituto de Estudios Peruanos, 2004). we know that elections occurred extraordinarily early in the Hispanic world and that its electoral base was not only multiethnic-incorporating indigenous communities, something that did not occur in the Englishspeaking world-but also that the voters were not mere actors performing according to somebody else's dictates. They knew precisely what they were doing when yoting, and they understood the importance of utilizing that political mechanism to defend their personal and group interests. ${ }^{6}$ Also, in this context of thematic, methodological, and interpretative renovation, a large number of works consider the municipality a form of collective organization with various levels of self-government, which Spanish America experienced throughout the Modern era. The autonomous city subsequently played a prominent role during the independence and republican periods, both in the Hispanic-Creole domain and in the indigenous world. ${ }^{7}$ This evidence suggests that it is necessary

6. There is a growing bibliography regarding the Indians's participation in the political system throughout the nineteenth century. See Sonia Alda, La participación indi gena en la construcción de la república de Guatemala, siglo XIX (Madrid, UAM, 2000). Rossana Barragán, Indios, mujeres y ciudadanos. Legislación y ejercicio de la ciudadanía en Bolivia (siglo XIX) (La Paz: Fundación Diálogo-Embajada del reino de Dinamarca en Bolivia, 1999); Marie-Danielle Demélas-Bohy. "Modalidades y significación de elecciones generales en los pueblos anđinos, 1813-1814", in Antonio Annino (coord.), Historia de las Elecciones en Yberoamérica, (Buenos Aires: Fondo de Cultura Económica, 1995), pp. 291313; Antonio Escobar Ohmstede, "Del gobierno indígena al Ayuntamiento constitucional en las Huastecas hidalguense y Veracruzana, 1750-1853" in Mexican Studies-Estudios Mexicanos 12:1 (Winter 1996), I-26; Clandia Guarisco, Los indios del valle de México y lo construcción de una nueva sociabilidad política, 1770-1835 (Zinacantepec: El Colegio Mexicanense, 2003); Ibid., Etnicidad y ciudadanía en México y Perú (1770-1850) (lima Documentos de Investigación, 84, 2004); Alicia Hernández Chávez; La tradición repubilicana del buen gobierno (México: Fondo de Cultura Económica-lil Colegio de México, 1993); Marta Irurozqui, "Las paradojas de la tributación. Ciudadanía y política estatal: indigenas en Bolivia, 1825-1900" in Revista de Indias 59:217, (1999), 705-40; "The Sound of the Pututos. Politization and Indigenous Rebellions in Bolivia, 1825-1921", Journal of Latin American Studies 32/1 (February 2000), 85-114; Jaime E. Rodríguez O., "Ciudadanos de la nación española. Los indígenas y el Reino de Quito", in Irurozqui (ed.), La mirada esquiva, 41-63. For a meditation on the roads opened by this historiography, see Mónica Quijada, "La caja de Pandora. El sujeto político indígena en la construcción del orden liberal", Revista de Historia Contemporánea, in press.

7. See among others Jordana Dym, From Sovereign Villages to National States; Antonio Escobar Ohmstede, "Del gobierno indígena al ayuntamiento constitucional en las Huastecas hidalguense y Veracruzana, 1750-1853", Mexican Studies-Estudios Mexicanos 12:1 (Winter, 1996),1-26; Francisco González-Hermosillo Adams, Gobiemo y economía en los pueblos indios del México colonial (Mexico: Instituto Nacional de Antropología c Historia, 2001); Claudia Guarisco, Etnicidad y' ciudadanía en México y Perú (1770-1850) (Lim, Documentos de Investigación, 84, 2004); Marta Iurozqui, "De cómo el vecino hizo 1830 " in Jaime E. Rodríguez O., coord., Revolución, independencia y las nuevas naciones de América, (Madrid: Fundación Mapfre, 2005), 451-484; ibid:, "Sobre el tributo y otros atri- 
to revisit the principle of the community as the essential source of legitimate power, a well as the contractual nature of politics in the Hispanic world.

The rapidity and the widespread nature of political change at the end of the eighteenth and the beginning of the nineteenth century in the Hispanic world are clearly related to the concept of popular sover eignty. However, this multifaceted concept and its widespread influence have been obscured by the rigid semantics imposed after the French Revolution. This work seeks to contribute to a necessary revision from the analytical perspective explained below.

In a previous work I argued that the secular construction of modernity, which developed in the Western world, entailed multidirectional transfers and reciprocal influences encompassing ideas and experiences as well as networks of power and thought. These transfers and mutual influences constituted a form of "shared imaginaries" that crossed borders and time periods, operating through fluxes and interweaving that need not be sequential or linear. ${ }^{8}$ The plural form is utilized here intentionally because I hold that no singular imaginaire operated with the same sequence and the same content in each instance and location. The methods of achieving Modernity were diverse, paralleling each nation's progress and experiences, though I believe these variations are but specificities located within the ample political processes common in the Western world.

Multiple elements contribute to the configuration of a political imaginaire; they range from practical action, including violence, to the most refined theories. Thought, although clearly only one of these elements, is the one on which this work will focus. It will examine the proposals advanced by Hispanic treatises of the sixteenth and the beginnings of the seventeenth centuries. Although initially written for the Peninsular world-in other words, European, the novelty generated by the discovery of America in general and, in particular, by the early conquest

butos ciudadanos. . . Regarding this topic see also Marcello Carmagnani y Alicia Hernández, "Dimensiones de la ciudadanía orgánica mexicana, 1850-1910" in Hilda Sabato (ed.) Ciudadanía política, 371-402; Tamar Herzog, "La vecindad: entre condición formal y negociación continua. Reflexiones en torno a las categorías sociales y las redes personales" in Anuario del IEHS 15 (2000), 123-131; Federica Morelli, "Entre el antiguo y el nuevo régimen: el triunfo de los cuerpos intermedios. El caso de la Audiencia de Quito, 1765 1830", Historia Política. Ideas, procesos y movimientos sociales 10, (2003), 163-190.

8. I am using the French term imaginaire, which was coined during the past years to denote the theoretical concept that is defined below whithin the text. See note 9 for references regarding the term. Mónica Quijada, "Las dos tradiciones. Soberanía popular e imaginarios compartidos en el mundo hispánico en la época de las grandes revoluciones atlánticas" in Jaime E. Rodríguez O. (coord.): Revolución, Independencia y las nuevas naciones de América (Madrid: Fundación Mapfre, 2005), 61-83 and occupation of lands, such as the one not casually called "New Spain" as well as the central Andean zone, contributed to the introduction of nuances and reconsiderations forged in a new foundry.

This work commences by isolating a specific perspective that focuses on the political domain. Located within this realm is a particular theme: the configuration of a principle that holds that true political legitimacy is based on the consent of the governed, that is, the community, and on the contractual nature of the origin of political power. The goal is to recover viewpoints that have been obscured by a historiography of the Hispanic world that has focused on some authors and excluded others who were as significant and as influential. Moreover, this work seeks to accentuate the unique aspects of that tradition in light of how historiography classifies diverse expressions of modern political thought in relation to their conservative or radical potential, which, in the end, foreshadow their relation with, and influence upon; the political changes of modernity.

Finally, this work maintains that in order to appreciate these relationships and influences, one must reconsider political thought from a viewpoint not centered in a world of readers and academic learningin which ideas, references, and texts are passed on among individuals or groups of individuals - but rather from a notion more flexible and much wider in scope: the concept of imaginaire referred to above. This notion encompasses the whole of the representations which societies produce, from which they perceive themselves, and from which they perceive their relations to their surroundings. The reality of these imaginaires resides in their very existence, in their impact on mentalities and behaviors, and in their capacity to influence decision-making processes. From this perspective, the imaginaire is the fundamental reference to which all human thought-processes revert. ${ }^{9}$ Here is where this work proposes to engage the texts, keeping in mind that they do not necessarily function through direct contact or sequentially and that they are only one of various elements that also contribute to the configuration of the political imaginaire.

This article begins its analysis by revisiting certain arguments that Quentin Skinner advanced in his seminal work, The Foundations of Modern Political Thought. ${ }^{10}$

9. See Branislaw Baczko, Les imaginaires sociaux. Mémoirs et espoirs collectifs (Patis Payot, 1984); Lucian Boia, Pour une bistoire de l'imaginaire (Paris : Les Belles Lettres, 1998); Cornelius Castoriadis, L'Institution imaginaire de la société (Paris : Seuil, 1975) Gilbert Durand, Las estructuras antropológicas de lo imaginario (Madrid : Taurus, 1981) [1st ed. in French: 1960]; Gilbert Durand, Limaginaire. Essai sur les sciences et la philosophie de l'image (Paris : Hatier, 1994); Jacques Le Goff, L'Imaginaire médieval (Paris, Gallimard, 1985)

10. Quentin Skinner: The Foundations of Modern Political Thought, 2 vols (CambridgeNew York: Cambridge University Press, 1998). 


\section{Francisco Suárez or the Conservative Solution}

Skinner begins the second part of his work, dedicated to constitutionalism, with a reference to Martin Luther, citing a passage written by the influential English historian John Neville Figgis at the beginning of the twentieth century: "Had there been no Luther there could never have been a Louis XIV". Skinner adds: "Figgis' epigram has been criticized as antihistorical, but there is no doubt that the main influence of Lutheran political theory in early modern Europe lay in the direction of encouraging and legitimating the emergence of unified and absolutist monarchies. Luther's doctrines proved so useful for this purpose that his most distinctive political arguments were eventually echoed even by the leading Catholic protagonists of the divine right of kings," "such as JacquesBénigne Bossuet. Skinner is referring to the well-known fact that Luther's opposition to the Papacy's aspirations to universal authority led him to defend the absolutism of the princes on the grounds of divine and nat ural law, by asserting that the princes' power derived directly from God and that all Christians were obligated to submit themselves unconditionally to political authority.

However [Skinner goes on] the sixteenth century not only witnessed the beginnings of absolutist ideology, but also the emergence of $i t s$ greatest theoretical rival, the theory that all political authority inheres in the body of the people and thus that-as Filmer put it in Patriarcha-all rulers must be 'subject to the censures and deprivations of their subjects." 12

Skinner then wonders how such thinking-labeled by Filmer "new, plausible and dangerous opinion"-would develop so dramatically that governments with absolutist pretensions in Western Europe were "eventually challenged by the first wave of successful political revolutions of modern times." 13

To this question, so important to political developments extending to present times, Skinner provides a response that integrates two principal components. The first deals with the formation during the Early Middle Ages of a considerable body of radical political ideas, reaching a new peak of development at the beginning of the sixteenth century; ". . . there was thus a large arsenal of ideological weapons available to be exploited by the revolutionaries of sixteenth century Europe. The other important point is that all the most influential works of system atic political theory which were produced in Catholic Europe in the

11. Ibid., vol.II, p.113.

12. Ibid., vol. I, 114-115. Italics added.

13. Ibid., vol.I, 115 course of the sixteenth century were fundamentally of a constitutionalist character." 14

The point being that the British author, concerned with tracking the "foundations of modern political thought," acknowledges the vital role played by the Salamanca School in the construction of the modern theory of the natural law of the State; that is, he demonstrates that Spanish theologians had an initial and seminal role in the configuration of this theory. What is important for Skinner is tracking precisely the implications of the Spanish theologians' debates regarding reason and natural right on subsequent developments such as those made by John Locke, the Levelers of the English Revolution, John Milton, and international law. Above all, he is interested in showing how these debates furnished a conceptual language and a model of political arguments that theorists, as important as Hugo Grotius, Thomas Hobbes and Pufendorf adopted later in developing the classical version of the theory of the natural law of the State. ${ }^{15}$

In this argument, Skinner's most important analysis concerns Francisco Suarez, ${ }^{16}$ whose theoretical developments he considers seminal because, in his view, they allowed the articulation of two basic tendencies in modern political thought: one that privileged monarchical absolutism and the rival theory that held that all political authority is inherent in the community. It was precisely the tension between these tendencies that permitted the construction of the modern State.

In other words, in a context that made it necessary to refute the princes' divine right to power, as defended by Luther, while at the same time safeguarding royal authority in a time of growing affirmation of absolutism in the majority of European states, the Spanish Jesuit, Francisco Suarez, offered a theoretical solution to the political problem that preoccupied everyone, regardless of their religious differences. ${ }^{17}$ Suárez joined the defense of man's natural liberty and the consent of the community as the only sources of legitimate power with the principle that

14. Ibid., vol. II, 115.

15. Ibid., vol. II, 184 .

16. Francisco Suárez (1548-1617)

17. Suárez's refutation of Luther's argument is found in two publications: De Legibus (1612) and especially in Defensio fidei catholicae et apostolicae adversus anglicanae sectae errores (1613). This latter work, which was not wrought from academic speculation, is most important. It originated in a Papal commission aimed at responding to the actions taken by King James I of England against the Catholics residing in his country. It should also be noted that the theories on the origin of political power posited respectively by Luther and Suarez had to do with the immediate and earthly necessities imposed by their time, rather than with theological, out-of-this-world elucidations. 
once the community had transferred its sovereignty to the ruling power, it was irrecoverable except in extreme cases where the very existence of the community itself was threatened. According to Skinner, without Suárez's precedent Hobbes would not have discovered the basic ideological tools to construct his Leviathan. ${ }^{18}$

If one adopts Skinner's interpretation, then one could conclude that Francisco Suarez resolved the tension between both poles of political thought in a conservative manner. His unique view, which united the defense of the potestas populi with the assertion that its al location of sovereignty was irrecoverable, save in extreme cases, was designed in the last instance to ensure order and hierarchy within the community. This is precisely the reason why Thomas Hobbesworried by the excesses and disorders of the English Revolutionincorporated Suárez's proposal as a fundamental thesis of his texts, which were universally considered to be decisive in the modern the ory of the State.

It is also important to note that Suárez's theses have been identified by a long and abundant historiography as the fundamental theories that the Hispanic political imaginaire extracted from its tradition of politica thought during the era of Atlantic Revolutions. I will return to this point later.

Skinner also observes that Suárez's English contemporaries were surprised that many Counter-Reformation theorists staunchly defended the cause of popular sovereignty. They supported it as much-Sir Robert Filmer stated-as the most "zealous favorers of the Geneva discipline."19 This observation is not trivial because in British historiography the Calvinists are granted a fundamental role in constructing the "radical" political ideas that served to nourish the triumphant revolutionary processes of the seventeenth century. ${ }^{20}$ However, although Skinner raises this topic, and though he examines certain aspects of the principle of consent in the Hispanic treatises, he does not address the question whether the Spanish Scholastic School should be included in the genealogy of thought that he labels radical, a genealogy that, in his opinion, extends from the proposals of Early Middle Age thinkers such as Saint Thomas Aquinas, William of Occam, Marsiglio of Padua, and Bartolus of Sassoferrato, through the Conciliary debates of Pierre D'Ailly and Jean Gerson, to the modern developments of John Mair, Peter Crock-

18. Skinner, The Foundations of Modern Political Tbought, vol. II, 182-4

19. Tbid., vol. III. 114

20. For a critique of this interpretation see Quentin Skinner: "Humanism, Scholasticism and Popular Sovereignty" in Ibid., Visions of politics. Vol. II Renaissance virtues, (Cambridge: Cambridge University Press, 2002), 245-263. aert, Jacques Alamain and, finally, to the late Reformation and the Calvinists. $^{21}$. That is the body of thought that would inspire the political changes espoused by the great modern revolutions.

As Skinner himself points out, he does not intend to reconstruct the process of linguistic configuration of the modern State in Spain, as he does in the case of England and France. He is not a specialist in Hispanic political thought and does not hide the fact that he utilizes that thought for purely instrumental ends. This is why I stop here with Skinner's proposal. From this point forward, this article will delve deeper into the scope and meaning of the potestas populi and the principle of consent in Hispanic treatises. It will examine the writings of certain Hispanic thinkers who have generally been obscured by the omnipresence of Francisco Suárez in all works that focus on the period, which consider Suárez's writings the most important Hispanic contribution to modern political thought.

\section{Thomist Roots and Radical Derivations}

To understand the context from which those works emerged, it is necessary to return to Spanish theologians who in the sixteenth century amazed the English with their defense, (imparted with as much zeal as the Calvinists), of the principle that all authority resides originally in the community. Such a defense is extremely logical if one considers that the Salamanca School was one of the centers that reintroduced and transmitted the ideas of the great thirteenth-century theologian Saint Thomas Aquinas. Moreover, the Hispanic thinkers-most of them were Dominican as was Aquinas, others were Jesuit and members of other ordersconsidered themselves his disciples.

The crux of Saint Thomas's political thought was the effort to reconcile the Aristotelian vision of the polis as a human creation formed for mundane ends with Saint Augustine's Christian perspective. In this sense, Saint Thomas opened the floodgates to political thought that would have enormous repercussions for centuries. This thought defended, through Christian lenses, the belief that all political power resides legitimately in the body of the community. It is this body that transfers sovereignty to a ruler through an act of consent. In the wake of Saint Thomas Aquinas, this principle would be defended by a majority of Spanish theologians from Francisco de Vitoria to Suárez, including Domingo de Soto, Fer

21. Saint Thomas Aquinas (ca.1225-1274), William of Occam (1288-1348), Marsiglio of Padua (1290-1342), Bartolus of Sassoferrato (1313-July 13, 1357), Pierre D'Ailly (13511420), Jean Charlier de Gerson (1363-1429), John Mair (1467-1550), and Peter Crockaert (c.1465-1514). 
nando Vázquez de Menchaca, Juan đe Mariana ${ }^{22}$ and others. For the purposes of this article, however, it is necessary to indicate that they not only shared much, but also differed among themselves. The existence of nuances and gradations in their thought is of great significance to understanding the nature of the construction of modern political thought.

The first of these thinkers, Francisco de Vitoria-a University of Paris student, heavily influenced by the teachings of John $\mathrm{Mair}^{23}$ through his disciples, Peter Crockaert and Jacques Almain ${ }^{24}$-is considered by many as one of the greatest advocates of the divine right of kings. In realityand this is crucial--Vitoria made two contradictory proposals in his wellknown relectiones (lectures) at the University of Salamanca. That contradiction has been overlooked by a majority of historians-including Skinner-but has been very well studied by two of the most important experts on this topic: Antonio Fernández Santamaría and Annabel Brett. ${ }^{25}$ On the one hand, Vitoria affirmed that the people elect the prince and gxant him authority to make decisions with respect to the republic, thus situating the origin of political power in the consent of the people. ${ }^{26}$ However, upon returning to this argument later, Vitoria insisted that power must be delegated by the community to a leader, preferably a king. But he also added that the king's power does not come from the community, but from God, and that the community does not grant power only authority. In the perspective of this new interpretation, the indi-

22. Francisco de Vitoria (ca. 1483-1546), Domingo de Soto (1494-1560), Fernando Vázquez de Menchaca (1512-1569), and Juan de Mariana (1536-1624).

23. John Mair-known also as Joannes Majoris-was the main figure to bring to the sixteenth century the works of Saint Thomas Aquinas and Early Middle Age theories deal ing with the Church's power and its limits, as well as the origin of civil power. Rooted in this tradition, Mair maintained that the authority of the Church inhered in the body of the Faithful, not in the Pope-a principle he projected on the civil world in which the peopleconand the Salamanca School's moral philosophy see Anthony Pagden, The Fall of Natural Mari. The American Indian and the origin of comparative ethnology (Cambridge: Cambridge University Press, 1982); Brian Tierney, The Idea of Natural Rights:Studies on Natural Rights, Natural Law and Cburch Law,1150-1625, (Atlanta: Scholars Press, 1997).

24. Jacques Almain (b? - 1515).

25. Annabel S. Brett, Liberty, Rigbt and Nature. Individual Rights in Later Scholastic Thougth (Cambridge: Cambridge University Press, 2003, 1st Ed. 1997); J.A. Fernández Santamaría, La formación de la sociedad y el origen del Estado. Ensayos sobre el pensamiento político español del siglo de oro (Madrid: Centro de Estudios Constitucionales, 1997). I have developed a portion of this análisis in Mónica Quijada: "Sobre 'nación', 'pueblo', 'soberania' y otros ejes de la Modernidad en el mundo hispánico", in Jaime E. RoL Las Nueuas Naciones: España y México, 1800-1850 ( Jación MAPTRE, 2008) 17-49.

26. Francisco de Vitoria (1486-1546): De postestate civili [1528-1549-a compilation of his lectures (relectiones) at the University of Salamanca]. vidual's subjective right does not play any role in the formation. of civitas. The agent that provokes the act is the impulse of preservation that God placed in mankind at the beginning.

This contradiction was considered incoherent by the Neo-Scholastics themselves. Suárez finally solved it decades later; he declared: "When civil power is legitimately invested in a man, it means that it comes from the people and from the community. Such is the opinion of Vitoria." He also added that Vitoria's defense of the divine foundation of royal power in one of his relectiones was due to fear (!). Fear of what? Suárez does not say, but one can imagine what it was since Vitoria lived at a time of growing authoritarianism and centralization of power in all parts of Europe. Furthermore, in Spain, the echoes of the terrible repression following the suppression of the rebellion of the Comuneros - the first, albeit defeated, modern revolution- ${ }^{27}$ were still resounding. According to Francisco Suárez's interpretation, Vitoria's private thought would resolve itself in favor of the principle that political legitimacy was founded on the consent of the community.

Suárez's interpretation veers away from the absolutist element of divine right initiated by Vitoria's contradiction. Furthermore, contrary to what one would expect if one were searching for linear antecedents of ideas, this contradiction did not inaugurate in Hispanic treatises an evolutionary process toward growing acceptance of absolutist principles, a trend that would have been in agreement with the general political tendency of the age and the Spanish Monarchy's growing authoritarian tendencies. On the contrary, most of the great thinkers who followed Vitoria defended the principle that power resided in the community and that body transferred its power through consent. Their proposals might vary in detail or scope, but all of them-from Soto to Suárez, as well as Vázquez de Menchaca, Juan de Mariana, and others-supported this theory grounded in Saint Thomas Aquinas's syncretic thought.

Furthermore-and this is the crux of my hypothesis-those Hispanic thinkers not only defended the principle of consent as a source of the legitimacy of power in Saint Thomas Aquinas' terms, but they also contributed certain elements to that theory that were not ever posited by Saint Thomas, but that on the contrary, opposed bis doctrine. In his Suma Theologica, Saint Thomas Aquinas stated that:

1. Even though "the consent of the people is essential in order to establish a legitimate political society, the act of instituting a ruler

27. For a more in-depth analysis of this thesis see Quijađa, "Las dos tradiciones." For work that argues that the revolt of the comunidades de Castilla was the first modern revolution, see José Antonio Maravall, Las Comunidades de Castilla (Madrid: Alianza Universidad, 1994), (1st edition published in Madrid: Revista de Occidente, 1963). 
always involves the citizens in alienating-rather than delegatingtheir original sovereign authority." 28

2. From which "it follows that all rulers must be genuine sovereigns who are legibus solutus, unfettered by any formal obligations to obey the positive laws." 29

Thus, according to Saint Thomas the community, through the act of consent, not only delegated power, but also alienated it. Furthermore, the legitimate ruler to whom the people had granted-not delegatedtheir sovereignty was not subject to the regulations of positive law that he himself introduced through that legitimate power. This proposal was taken up toward the end of the sixteenth century by Jean Bodin and later by Hobbes ${ }^{30}$ However, many Spanish Scholastics refuted, or simply ignored, this aspect of Thomist thinking. They did so to different degrees because they did not constitute a single ideological group but represented multiple theoretical views. Domingo de Soto, for instance, stated that man was not only a member of the community, in whose survival he played an important role, but also that be is entitled to bis own rights as an individual who exercises control over those rights. In other words, man was the subject of bis own rights and ought to bave full control over bis own liberty. ${ }^{31}$ That is to say, Soto incorporated into his political theory the notion of the individual, and as early as 1553 , he advanced the principle of the individual as a subject of laws over which he maintained control, that is, sovereignty.

In a text published in 1564 , Fernando Vázquez de Menchaca contributed a unique perspective to the problem. ${ }^{32}$ In typical Thomist

28. Skinner, The Foundations of Modern Political Thought, 62

29. Tbid.

30. "... if the Prince is exempted from the laws of his predecessors, much less will he be obligated by the laws and norms he himself dictates, because $(\ldots)$ it is impossible by nature to give oneself law" [" $\ldots$ si el príncipe supremo está exentado de las leyes de sus predecesores, mucho menos será obligado a las leyes y ordenaciones que él bace, porque (...) es imposible por natura darse ley a sí propio ${ }^{2}$. Juan Bodino: Los seis libros de la República. Traducidos en lengua francesa y enmendados catbolicamente por Gaspar de Añastro Isunza. Edited with an Introduction by Josè Luis Bermejo Cabrero (Madrid: Centro de Fstudios Constitucionales, 1992) quote in Vol. I, 276 " . the will of the CounCill or one who hath the Authority given him, is the will of the City; he therefore containes the wills of particular Citizens. Therefore neither is he bound to the Civill Lawes (for this is to be bound to himself) nor to any of his Citizens, "Thomas Hobbes: $D e$ Cive. Pbilosophical Rudiments Concerning Government and Society, 1651, Ch. Vi, "On Dominion", paragraph 14. Jon Roland (ed), Liberty Library of Constitutional Classics (www.constitution.org/liberlib.htm).

31. Domingo de Soto (1494-1560), De iustitia et iure [1553-4]. Brett, Liberty, Right and Nature, 159.

32. Fernando Vázquez de Menchaca (1512-1569), Controversiarum illustrium usuque frequentium (Venice: Imprenta de Francisco Rampaceto, 1564). Bilingual edition thought, he insisted on the original and universal liberty of man and asserted that every ruler obtained his power from the consent of the city that elected him. To that original liberty, Vázquez de Menchaca linked the inalienable principle that the power of the prince-elected "neither because of his person nor for his own good, but rather in service of the community and for the common good"-was of limited and temporal nature. ${ }^{33}$

According to Vázquez de Menchaca, whose writings circulated widely, ${ }^{34}$ authority emerged from the natural inclination of men to form society. Since discord and dissent arose as a result of social life, society created authority and political civil power to resolve those questions. That is why he maintained that such authority belonged in the domain of natural law. Its origin, however, is indisputably contractual, because that supreme authority always stemed either from a grant or from election. And he added, "It is worth noting that there can be frequent changes and variations (and sometimes it is even convenient for this to occur) in the ruling persons, as well as in circumstances of place, time, and causes, and methods of ruling and governing." Not only was the transfer of sovereignty revocable, but also it was "the king who ought to submit to the laws, not the laws to the king;" that was why the prince's decree only "has the force of true law, as regards its implementation, if it is aimed at the public good." 35

Vázquez de Menchaca also added a series of conclusions about the nature of power that are of extraordinary interest. On one hand, he affirmed that power is an artificial situation favored by wealth; ". . . whoever has the most wealth is considered the most powerful, and therefore the most noble and superior." 36 On the other hand, he introduced a difference between potestas and potentia, which had to do with the debate on political legitimacy. Potestas is the power that citizens con-

in Latin and Spanish: Controversias fundamentales y otras de más frecuente uso expuestas en tres libros por el jurisconsulto vallisoletano Don Kernando Vázquez de Menchaca, Miembro del Supremo Consejo de Hacienda del Católico Rey de las Españas D. Fetipe, 4 vols. (Valladolid: Universidad de Valladolid, 1931), translated by the Catedratico Instituto D. ridel Rolígez and prefoce by Catedrútico de Universidad D. Calixto Valverde.

33. Vázquez de Menchaca, Controversiarum illustrium usuque frequentium, Book I, Introduction-121, p. 79.

34. His Controversiarum cited here, was reprinted many times. Even today, as I have been able to confirm, this work can be found by the score in major public European $\mathrm{H}$ braries. It is also important to note that Vázquez de Menchaca was greatly influential among significant thinkers such as Grotius or Pufendorf, who openly recognized such inffuence. Not in vain, as Anabel Brett shows, Grotius called him "the glory of Spain."

35. Vázquez de Menchaca, Controversiarum illustrium usuque frequentium, Book I, Chap.I-8, p.99. The subjugation of the ruler to the laws is the major theme in this chapter 36. Cited in Brett, Liberty, Right and Nature, 169. 
cede to the prince so that he may look after the common good, and its exercise is limited by law. It is a legal power, obligating those who are under its jurisdiction as well as the individual who exerts such power. Potentia, on the other hand, is a power exercised by the prince that has nothing to do with law. It is de facto power, not legal power, and thus can be unstable as well as mutable. However, potentia is effective in daily life because it concedes prelatio (precedence) to "one" over the community. Prelatio, according to Vázquez de Menchaca, is the superior position assumed by an individual over everyone else due to power bestowed by wealth. In other words, it did not derive from the legitimacy granted by consent, but rather from a fortuitous circumstance that had placed the one who exerted potentia in a propitious asymmetrical situation, favoring him with respect to his fellow citizens.

Thirty years later, in 1599, another very important text was published: Jesuit Juan de Mariana's De rege et reges institutione. In Mariana's scheme, men associate themselves in order to share a communal life and create rules permitting them to "live under one law, irrespective of social differences." 37 For pragmatic and utilitarian reasons the community opted to surrender part of its authority to a ruler. This transfer of power, however, was neither unconditional nor absolute because "the republic, in which regia potestate originated, may call upon the king to abide by the law when circumstances so demand and may even take away the king's power, should his injurious conduct against the community persist." This was possible because when it transferred its power to the king, the community reserved for itself a higher potestas than the one it conceded to the latter. ${ }^{38}$

Thus Mariana located the origin of society in the free will of the community. It is from that society that law emanated and it was the community who chose to place a ruler at its head. The Jesuit theologian favored a type of government based on a restricted monarchy (constrictum) that required the consent of the community. This led him to a make a statement that in his time-a period of growing absolutism and centralization of power-was extremely radical. Mariana affirmed that the au-

37. ["vivir bajo un mismo derecho sin distinciones por su condición social"]. Juan de Mariana, La dignidad reat y la educación del rey, edition and preliminary study by Luis Sánchez Agesta (Madrid: Centro de Estudios Constitucionales, 1981) [1599], Chapter.I, 23. For an indepth analysis see Fernández Santamaria, La formación de la sociedad y el origen del Estado, pp.213-255.

38. ["la república, en la que tiene su origen la potestad regia, puede, cuando las circunstancias así lo exigen, llamar a derecbo al rey e incluso, si persiste en su conducta injuriosa a la comunidad, quitarle el poder']. Mariana, La dignidad real y la educación del rey, Chapter VIII. Sce Fernández Santamaría, La formación de la sociedad y el origen del Estado. thority of the community as a whole was greater than that of a single man; ultimately, Mariana legitimized and even praised tyrannicide. ${ }^{39}$ It is worth observing that the perception of the subversive potential of the ideas contained in the De rege et reges institutione was so significant in his time that in 1610, following the assassination of French King Henry IV De Rege was burned at the stake by the official executioner, following a public trial in which Mariana's text was accused of having instigated the regicide. ${ }^{40}$

Returning to the political arguments in Mariana's text, one of the Jesuit's most interesting propositions inverted the hierarchy usually associated with monarchical principles, whether absolute or limited. He affirmed that the transfer of sovereignty implied an asymmetrical order in which superiority was held by the community, since it reserved for itself one part of the potestas as well as the right to dispossess the king of power, should the latter not abide by the conditions stipulated in the initial pact. Mariana also established the principle of division of powers: The community maintained the capacity to impose tribute and to change laws (or eliminate those deemed unsuitable) as well as to intervene in matters related to the succession to the throne. It fell to the king to declare war, provide laws in times of peace, and elect justices and magistrates.

Thus, despite the fact that they were not only Thomists but also the most important revivalists of Early Medieval Thomism in the sixteenth century, these and other Spanish thinkers distanced themselves from some of Saint Thomas Aquinas's postulates in order to follow the extreme derivations of some of his most rebellious and radical disciples, such as Marsiglio of Padua and Bartolus of Sassoferrato. ${ }^{41}$ In the thirteenth century and during the beginning of the fourteenth century, both Marsiglio and Bartolus had maintained that, though the community consented to

39. Mariana, La dignidad reat y la educución del rey, Chapters V-VII; Fernández Santamatía, La formación de la sociedad y el origen del Estado. For a history of tyrannicide, see Mario Turchetti, Tyrannie et tyrannicide de la Antiquité à nos jours (Paris: PUF, 2001).

40. Keep in mind that Mariana's text, though published in 1599, had been written in 1590 and the example of the tyrannical king whom the text refers to, specifically, is Henry IV's predecessor. In fact, in an earlier manuscript, Mariana acclaimed the regicide of Henry III by Jacques Clément (Ch. 6, Book I), a passage that the author sensibly modified for publication ten years later. See Georges Sirot, Mariana bistorien (Bordeaux : Feret et Fils; Paris, Albert Fontemoing, 1905), 35.

41. Marsiglio of Padua (1275-1343), Defensor pacis; Defensor minor. Bartolus of Sassoferrato (1313-1357), Tractatus de Regimine Civitates; Tractatus de Tyrannia. Marsgilio, Bartolus, and their contemporary Remigio of Girolami (?-d.1319), The Common Good The (rood of Peace) introduced a new vision of Rome, in which the period of the Republic was valued much more than the Empire. 
transfer its sovereignty to a king or a supreme magistrate, the latter could never be the legislator in an absolute sense but only in a relative and temporal one. The ultimate authority would always remain in the hands of the people who could supervise and even remove its rulers if they did not act according to the strictly limited powers conferred to them. ${ }^{42}$

Both Bartolus and Marsiglio assumed that "the people will in fact wish as a matter of convenience to delegate their sovereign authority," but will also wish to "ensure that the actions of the pars principans are in fact kept fully under the ultimate control of the sovereign body of the people." A mechanism was thus necessary to ensure that the actions of the person to whom the community had transferred its potestas remain under the sovereignty of the people. Both thinkers provided the same response: The solution resides in the principle of elections. The kings were officials appointed to administer law for the common well-being; furthermore, in Marsiglio's words, "For the sufficiency of civil life it is absolutely better for the commonwealth that each monarch be named in a new election rather than by hereditary succession. ${ }^{243}$ In this same vein, Bartolus added that no election that "is made 'in fear' should be regarded as valid, since "jurisdiction must always be voluntarily transferred." 44 Ptolemy of Lucca-a disciple of Saint Thomas who completed his unfinished work The Rule of Princes-also opted for election instead of inheritance. Moreover, he admired the government of the ancient Roman Republic based on the annual election of all significant positions. ${ }^{45}$

These were the political principles that, incorporated in the Western European imaginaire, came to influence the radical thinking of the mod-

42. Skinner, The Foundations of Modern Political Thought, Vol., I, 62. Although he was not the first to point this out, we owe to Skinner a clear demonstration that "the belated yet brilliant flowering of scholastic studies in the Italian universities in fact made a contribution of fun (Vol, 1,499 . Walter Ulman is an important precedent to Skinner: See Walter Ullman, $A$ History of Political Thought:The Middle Ages (Harmondsworth: Penguin Books, 1965). The notion that they both defend has modified the traditional interpretative perspective claiming that there was an insuperable breech between Medieval scholasticism and humanism. For an account of the scbolasticism/bumanism debate and the interaction of both tendencies in their time period, see inrique González Conźlez "La crítica de los humanistas las universidades. El caso de Vives"in Ty. Fen Luis Vives y el Humanismo Europeo, (Valencia: Universitat de Valencia, 1998), 13-40.

43. Marsiglio of Padua, Defensor pacis, cited in Skinner, The Foundations of Modern Political Thought Vol., 1,63 .

44. Bartolus of Sassoferrato, A Tract on Civil Government and A Tract on Tiranny, cited in Skinner, The Foundations of Modern Political Thought, Vol., I, 63.

45. In the Middle Ages, The Rule of Princes was believed to have been composed solely by Saint Thomas Aquinas. Today we know that he left his work uncompleted, and his disciple, Ptolomey of Lucca, was the author of most of Book II as well as Book III and IV. Skinner, The Foundations of Modern Political Thought, Vol., I, 53-54 ern era by providing the principal tools with which to oppose the growing absolutism of monarchies. They formed a corpus of ideas defending the natural liberty of man, the consent of the community as the only source of legitimate power, the subjection of authority to law, the common good as the ultimate aim of the transfer of sovereignty, and also, the possibility of sovereignty reverting to the people's hands in various degrees that included the delegation of power via elections. These principles permeated the most important political traditions of Western Europe. In the Hispanic world, as we have seen, they were adopted by various thinkers who, though considering themselves Thomists, surpassed the limits of Saint Thomas Aquinas's thought. In certain cases they did so through daring contributions, such as those of Mariana's, or through proposals that were original and almost avant-la-lettre, as was the case with Vázquez de Menchaca. ${ }^{46}$

It is important to note that in order for these radical principles to have the greatest impact, they had to be recast in accordance with the contextual changes that had developed from the sixteenth century forward. Civitas expanded to become the State in its modern dimension implying a sense of territorial and political totality that prefigured the "national." In addition, the increasing autonomy of politics with respect to morals emerged. ${ }^{47}$ This was also the time when the early occupation of the lands to the west, which would come to be called las Indias (the Indies), began to expand. This expansion involved confronting a new and remote reality alien to.Europe and contact with a hitherto unknown population through an act of conquest that established a hierarchy of dominion. In the Hispanic world, this new reality led to the rise of political thinkers who incorporated new perspectives to the radical theories that have thus far been discussed. The confrontation-direct and

46. There are cases in which this type of thought resurfaces almost literally. In Mariana's De rege et reges institutione, for instance, there is a notable nearness to some of the theses developed by Marsiglio in his Defensor Pacis, such as his statement that the power of the people is superior to that of the prince, due to the former having held powe of vigilance over the actions of the latter to the extent that the ruler can be removed by the community. In Marsiglio's text, there is also a division of powers avant-la-lettre, which, with certain variants, prefigures Mariana's model. In the same way, the distinction introduced by Ptolomy of Lucca between political and despotical regimes (with and without legal basis) prefigures the contraposition furnished by Vázquez de Menchaca between potestas and potentia.

47. As Michel Senellart points out, the medieval idea of régime (in which the direction of the community is explained utilizing the metaphor of the pilot guiding the ship) give way to the modern conception of gouvernement (Les arts de gourverner. Du régime médiéval au concept de gouvernement (París : Seuil, 1995). Cfr. Anthony Pagden, The Fall of Natural Man. The American Indian and the origin of comparative ethnology Fall of Natural Man. The American Indian and the origin
(Cambridge: Cambridge University Press, 1982), Ch. 1 and 2. 
personal in some cases-with a new and complex reality caused some Hispanic thinkers to revise the scope of projection of the potestas pop uli, even though that meant questioning the Paris scholars, and even Aristotle himself.

\section{Radical Thinking and Conquered Populations}

Saint Thomas's syncretic thought, based on the reconciliation of Aristotle's Politics with the Christian perspective of Saint Augustine, had not only required the recuperation of the perspective of the Aristotelian political subject but also established its limits. These limits well suited the political universe of Saint Thomas's most radical disciples; in other words, the cives in the Italian experience. Ptolomy of Lucca-a disciple of Saint Thomas in Paris and writer of the final portions of Saint Thomas Aquinas's unfinished work, The Rule of Princes-distanced himself from his teacher because he preferred, just as Marsiglio had, an "elected" form of political system rather than a hereditary monarchy. However, in Saint Thomas Aquinas' text, which he was completing, Ptolemy maintained that these types of political principles function only where the community appreciated its liberty, as was the case in his native Italy. In other words, these principles could not be applied to every community since "some areas of the world are more suited to servitude than to liberty." 48

This mode of thought had its roots in the well-known Aristotelian classification that differentiated between those who congregated to establish cities and to give themselves governments in order to live in law and order (in other words, men who were political subjects) and those who did not have the capacity to communicate by language and, therefore, lacked the power to form civil and political societies. Such groups, who were deprived of a political life, were gathered by Aristotle under the category of barbaroi. From this perspective, bárbaro (barbarian) is the antonym of civil and political, concepts originating in the terms cives and polis (latin and Greek, respectively). These concepts, and their derivations, were applied both to the cities and to those who constructed the cities. ${ }^{49}$ They also included those who had uso de razón (the capacity of reason) and, therefore, the only beings who were free by nature. In contrast to them-as Aristotle's Politics reminds us-barbaroi were servants by nature and it was fitting that they serve those who possess reason, that is, free men.

That classification was utilized in the Middle Ages to identify mythical, rather than real beings (such as savages and/or anthropophagi, lan-

48. Cited in Skinner, The Foundations of Modern Political Thought, Vol., $1,54$.

49. See Anthony Pagden, The Kall of Naturat Man. guage-deprived men living contra natura), and it was associated with peoples believed to be culturally and mentally inferior. What is relevant for this analysis is that in early sixteenth century, the Parisian scholar John Mair applied this ancient classification to the recently discovered populations in a statement that was to have extraordinary repercussion: "These peoples [the inhabitants of Antilles] live like beasts on either side of the equator; and beneath the poles are wild men (. . .). And this has now been demonstrated by experience wherefore the first person to conquer them, justly rules over them, because they are by nature slaves." 50 By experience, that is to say, through the first contact with beings who were no longer mythical, but very real: the inhabitants of the Antilles discovered by Columbus. Thus newly encountered Indians were lumped together with those human groups that had been labeled as "more fit to servitude than to liberty." From this perspective, applying to those populations the radical principles with which the Modern Age was starting to oppose the expansion of absolutism would not be easy.

As is well known, the Aristotelian principle of the natural servitude of some of humankind, as applied to the Indians-and reinforced by John Mair's acknowledged auctoritas-was the model used to explain the reasons for the Indians' mores ${ }^{51}$ in the debates concerning the legitimate titles of the King of Spain to exercise dominion over the new lands, as well as certain policies deriving from such titles. In reality, several debates developed in different times during the sixteenth century, all of them

50. Mair continues as follows: "As the Philosopher says in the third and fourth chapters of the first book of the Politics, it is clear that some men are by nature slaves, others by nature free; and in some men it is determined that there is such a thing [i.e., a disposition to slavery] and that they should benefit from it. And it is just that one man should be slave and another free, and it is fitting that one man should rule and another obey for the quality of leadership is also inherent in the natural master On this account the phibsopher says in the first chapter of the aforementioned book that this is the reason why the Greeks should be masters over the Barbarians because, by nature, the barbarians and slaves are the same." Cited by Pagden, The Fall of Natural Man, 38-39.

51. It is important to point out that the concept of natural slavery, as defined by Aristotle-and applied by Mair and his subsequent followers in the famous debate regarding the legitimacy of the Spanish Crown's domination over the New World - did not make reference to a civil institution, but to a concrete category of humans defined in anthropologic terms. As Pagden states, "The origin of natural slavery is to be found neither in the action of some purely human agent, nor in the hand of God, but in the psychology of the slave himself and ultimately in the constitution of the universe" (42). In fact many cultures made similar categorizations that hierarchically differentiated between $u s$ and the others, like the Aztecs and the Incas in America. This distinction is important because, as Pagden remas, "any jugment on the nature of the Indians-and this utimtely bate over the justice of the conquests turned on-had thus to have its origin in a scheme which offered an explanation for the structurc of the whole world of nature and the behaviour of everything, animate or inanimate, within it" (The Fall of Natural Man, 53). 
after Queen Isabel la Católica's testament declaring that Indians should not be enslaved because they were her vassals and ought to be "treated justly and well." The earliest debates took place in two juntas: the one summoned by King Fernando el Católico in 1504, and the one gathered in Burgos in 1512. After 1530 a series of discussions occurred in which various members of the Salamanca School took an active part. Vitoria's treatise De Indis, ${ }^{52}$ and in 1550-1551, the controversy over the legitimate tỉtles confronting Bartolomé de Las Casas and Juan Ginés de Sepúlveda were the highlights of such debates. One final moment corresponds to the discussions produced ten years later with regard to whether the encomiendas should be eliminated or granted in perpetuity. One of the main outcomes of these debates was Las Casas's late text De regia potestate.

These debates would have an enormous, albeit not sufficiently valued, influence upon the development of many of the most important principles of modernity - such as the rights of the people, international law, the liberty of the seas, the liberty of commerce, the liberty of move ment, etc. The most distinguished authors later involved in such developments, like Grotius, Pufendorf, or Vatel, were inspired by and based their texts on treatises that had been elaborated as part of, or following, those debates.

It is not the aim of this article to deal with them in detai ${ }^{53}$ but merely to indicate that Vitoria and his disciples had never distanced themselves so much from their admired John Mair, as they did with respect to his identification of the New World Indians with Aristotle's natural servants, allegedly incapable of liberty and political life. In light of the new context furnished by contacts with the high cultures of Mexico and the Andes, Francisco de Vitoria situated the Indian "problem".within the level of relations among the diversity of human groups, within what he denominated "res publica totius orbis" (the republic of the entire world). ${ }^{54}$ He recognized Indians as rational beings and confirmed their right to have and maintain properties, irregardless of their psychology or their heretical condition. ${ }^{55}$ Vitoria's intervention in De Indis is crucial for the

52. Relectio de Indis, dictated in 1539 , circulated widely in manuscript until it was published in 1557

53. The most complete analysis, in my opinion, is Pagden's work previously cited. For partial aspects, especially those referred to the intervention of Bartolomé de las Casas, see the "Estudio Introductorio," written by Luis Pereña, with the collaboration of José María Pérez Prendes, Vidal Abril Castelló and joaquín de Azcárraga Server in Bartolomé de las Casas, De Regia Potestate.

54. Pagden, The Fall of Natural Man, 98.

55. Francisco de Vitoria, "Relección de los Indios recientemente descubiertos" $D$ De Indis], in Retecciones del Estado, de los indios, y del derecho de la guerra, Introduction argument in this article because his ideas provided the basis for the the New World's inhabitants to be recognized as capable of civic life and political organization: "Because in reality they are not dumb, since in their own way they exercise the use of reason. That is evident, because their affairs follow a certain order. They have, in effect cities, requiring order, and they have established marriages, magistrates, lords, laws, artisans, markets, all of which require the use of reason. Furthermore, they have also a form of religion, and do not err either in questions that others find self-evident, which is an indication of the use of reason." ${ }^{56}$ Vitoria's argumentation invalidated the Aristotelian principle of "natural slavery" to such an extent that a few years later-in 1564--Váquez de Menchaca would define such a principle as "Aristotle's unforgivable guilt." 57

However, despite recognizing the Indians' rationality and capacity to form families, cities, and commerce, the Dominican doubted that they could "rule themselves" and, therefore, he did not even consider it possible for them to be protagonists of the contractual principle. For such an idea to be raised it would be necessary to wait for thinkers who had had direct contact with Indians-particularly with New Spain's high cultures-such as Alonso de la Vera Cruz and Bartolomé de las Casas.

by Antonio Gómez Robiedo del Colegio Nacional (México: Editorial Porrúa, Col. Sepan Cuántos Núm. 261, 1974); Relección primera, 23-36.

56. i"Porque en realidad no son amentes, porque a su modo ejercen el uso de la razón. Ello es manifiesto, porque.tienen establecidas sus cosas con cierto orden. Tienen, en efecto, ciudades, que requieren orden, y tienen instituidos matrimonios, magistrados, señores, leyes, artesanos, mercados, todo lo cual requiere el uso de razón. Además, tienen también una especie de religión, y no yerran tampoco en las cosas que para los demás son evidentes, lo que es un indicio de uso de razón"]. Ibid., 36. Vitoria's final ar gument: ". . I think that if they appear to us as dull and obtuse it is mostly due to a bad and barbarous education, since not even among us is there a scarcity of rustics somewhat ture nos parezan tan idiotas $y$ parte de la mala y bürbara educación, pues tampoco entre nosotros escasean los rústicos poco desemejantes de los animales'] [ 36]) would be utilized in the future by many defenders of the Indians' natural liberty and political capacity, since denying them such condition would be like refusing it also to the people of the Peninsula, at their socially lowest and least educated strata. As Pagden shows, from De Indis on, culture and educationboth modifiable-would be the criteria used to analyze the social and political condition
of the Indian (see 148).

57. ["la imperdonable culpa de Aristóteles"]. Vázquez de Menchaca, Controver siarum, Chapters $\mathrm{I}-5,9$. It should be noted, however, that Vázquez de Menchaca explicitly refuses to enter into the debate regarding the justice of the Spanish monarch's dominance over the habitants of the Indias, "an opinion I neither approve of nor disapprove apruebo, ni repruebo, porque al presente no tengo tiempo para estudiarla o para es cribir sobre ella $\left.{ }^{j}\right](\mathrm{Ch} . \mathrm{X}, 236)$. In such a context and making reference to the Indians of the New World, he dedicates the tenth chapter of the first book to refuting the Aristotelian principle of natural enslavement: 
They both defended the Indians' capacity to rule themselves and to be recognized as the original community from which legitimate power was derived. Such a perspective conferred on the Indian the condition of subject of politics, that is, the holder of the initial potestas who took part in the affairs of his Republic--in other words, a citizen.

The Bishop of Chiapas, Bartolomé de las Casas, utilized the principles of political legitimacy founded on the consent of the community and the capacity for restitution of sovereignty to its original source as expressed in the most extreme forms of Marsiglio's and Bartolus' radical thought. ${ }^{58}$ This is particularly apparent in a late text-De regia potestate (1566)-designed to delineate the powers and obligations of the Spanish monarch with regard to las Indias and its inhabitants. Las Casas started with the proposition that man possessed natural liberty and that he was a "social animal" in order to affirm the principle of popular sovereignty as the only source of legitimacy: "The power of sovereignty derives directly from the people. And people are the creators of kings or princes and of all rulers, if they had at all a just origin." ${ }^{59}$ Furthermore, the transfer of sovereignty to a prince or a ruler was made through an act of "free election," and that initial consensus based on an election defined the limits of the power that had been transferred:

If the people were the efficient or effective cause, and also the final cause of kings and princes, so that the origin of the latter resided in the people by means of free election, they [the rulers] could not impose tribute and services from the beginning, beyond those which the people themselves were willing to accept. The consequence is clear: whenever the people elected their princes or king, they did not lose their own liberty. . . Later, it became necessary for the community's consensus to intervene so that it could not be taxed, nor deprived of its freedom; nor could harm be inflicted upon the community ${ }^{60}$

58. Bartolomé de las Casas (1484-1566) was named Bishop of Chiapas in 1544 and lived in his diocese until 1547. His first contact with the babitants of the New World was in the Antilles: From 1502 to 1506 he participated in the first Spanish colonization and received Indians in encomienda. He relinquished it in 1514 and joined the Order of Santo Domingo in 1522

59. ["El poder de la soberanía procede inmediatamente del pueblo. Y es el.pueblo la causa efectiva de los reyes o principes $y$ de todos los gobernantes, si es que tuvieron un comienzo justo"]. Bartolomé de las Casas, "De regia potestate"o Derecho de autodeterninación, (1566). Bilingual critical edition by Luciano Pereña, J.M. Pérez Prendes, Vidal Abril and Joaquín Azcárraga (Madrid: Consejo Superior de Investigaciones Científicas, Col. Corpus Hispanorum de Pace, 1969), 34-35.

60. [“. . si el pueblo fue la causa efectiva o eficiente y también la causa final de los reyes y los príncipes, de forma que tuvieron su origen en el pueblo a través de elecciones libres, no pudieron desde el principio imponer más tributo y servicios que los aceptados por el pueblo mismo y a cuya imposición bubiera él consentido de buena voluntad. La consecuencia es clara: cuando un pueblo eligió sus principes o su rey, no
This was so because "it was the people who decided and agreed to elect and give themselves kings, princes, and chiefs as a means to obtain their own ends, which consist of progress and service, and the promotion and protection of the collective welfare, since the people are their own cause." 61

Las Casas also reasserted another basic principle of the Thomismderived radical thought: that all public authority was subject to the laws of the political community "since they [the rulers] have over their subjects a power that is not their own, but the law's, and which is subjected to the common good. For this reason, the subjects are not bound by the potestas of the king, but rather by the potestas of the law." And, since the king or ruler "does not have either liberty or power to command the citizens arbitrarily and at the whim of his desire, but only in compliance with laws deriving from the political community, the king's decisions that are harmful to the people will be null and void." ${ }^{62}$ Finally, the king's jurisdiction could not obstruct the natural liberty of the subject: "From which follows that the dominium (as it is improperly called) that kings hold over their kingdoms ought not to impair the liberty of the citizens." With the term citizens-inhabitants of the cives- the Dominican was making a specific reference to the Indians, who ought to preserve their liberty and their possessions, even though they chose to become vassals of the Catholic King. ${ }^{64}$

Alonso de la Vera Cruz-who in 1553-1554 was appointed to the chair of the Prima Teología of the Royal University of Mexico after eight years

$\overline{\text { perdió su propia libertad (...). Luego fue necesario que interviniese el consenso del }}$ pueblo para que no se le gravase, ni se le privara de su libertad, ni se infiriese violencia alguna a la comunidad']. Ibid.

61. ['el pueblo fue quien decidió y aceptó elegir y nombrarse reyes, príncipes $y$, jefes como medios para conseguir sus propios fines, que consisten en el progreso y servicio, promoción y salvaguardia del bienestar colectivo, puesto que el pueblo es causa de sí mismo']. Ibid., 47-52.

62. ["Pues tienen sobre los súbditos un poder que no es suyo propio, sino de la ley, y que está subordinado al bien común. Por esta razón los súbditos no están sometidos a la potestad del rey, sino que están bajo la potestad de la ley". (Y, si el rey o gobernante) "no tiene libertad ni poder para mandar a los ciudadanos arbitrariamente y al capri"no tiene libertad ni poder para mandar a los ciudadanos arbitrariamente y al capricho de su voluntad, sino únicamente de acuerdo con las leyes de la comunidad poin

63. ["Por donde resulta que el dominio (como se llama impropiamente) que tienen los reyes sobre sus reinos en nada debe perjudicar a la libertad de los ciududanos? Ibid., 37-39. For analyses of this text, see the preliminary study by Luis Lureña, in the edition currently under usage, as well as Mauricio Bechot, Bartolomé de las Casas (14841566) (México: Ediciones del Orto, 1995); Ibid.: Historia de la Filosofía en el México Colonial (Barcelona: Hẹder, 1996).

64. See Bechot: Bartolomé de las Casas, 40. The meanings attached by Las Casas to key concepts like domination or jurisdiction are outside the scope of the present work. 
of missionary and pedagogical labor in the Tarascan region-maintained that all just dominion of men over men derived from the same community over which it was exerted; that is, from the republic. ${ }^{65}$ Therefore, "if someone exerts dominion by right, it is necessary that it be by the will of the community which has transferred its dominion unto others, as it occurs with aristocratic or democratic rule or to one alone, as is the case with monarchical rule." ${ }^{66}$ And if dominion was exercised in a tyrannical fashion, "in such a case the king or the emperor would exceed the potestas that was conferred upon him; and if the community either protests or does not consent, such a grant would not be valid." ${ }^{\prime 67}$ When concession was not made by free will, but by violence, whoever received it was obligated to restore it (retroversion) to the original community. There was no doubt as regards who this latter might be: ". . those who in these parts have a pueblo (town), entirely or partially, without someone's concession, they possess it unjustly when it is against the will of the people and against the will of the people's ruler, whom they call cacique, and they [therefore] possess it through force and violence. . . ; and they cannot be absolved unless restoration has been made; and restoration must be made either to the community itself or to the lord of that community, whether he be their own king or some other particular lord." 68

65. Alonso Gutiérrez professed under the name of Fray Alonso de la Vera Cruż (ca. 1504/7-1584), and as such he arrived in New Spain in 1536. He had been Vitoria's disciple in Salamanca. Fray Alonso began his mission labor in the Tarasca region, where he not only preached but also founded the first College of Higher Studies in Phisophy, as well as the first library ever opened in America (Tiripetio, 1540, and later in Tacámbaro and Atotonilico). In 1553 he was appointed to the Cátedra de Prima Teología in the recently created Real Universidad de México. In this context, he wrote De dominio infidetium et iusto bello, where he applied to the Indians the political ptinciples discussed in this work. See Fray Alonso de la Vera Cruz, Sobre el dominio de los indios y la guerra justa, Edition, Introduction and Notes by Roberto Heredia Correa, Presentation by Ambrosio Velazco Gómez (Mexico: Facultad de Filosofia y Letras, UNAM, 2004). See also Ambrosio Velasco Gómez, "Fray Alonso de la Vera Cruz y las Humanidades en la Ciudad de México" in Leticia Pérez Puente y Enrique González González, Permanencia y Cambio II. Uni versidades Hispánicas (México: UNAM, 1998), 526-533.

66. ["es necesario, que si alguien tiene dominio justo, éste sea por voluntad de la comunidad, la cual transfiere el dominio a otros, tal como sucede en el principado aristocrático o democrático, o a uno solo (como sucede en el principado monárquico)." Fray Alonso de la Vera Cruz, Sobre el dominio de los indios y la guerra justa, Duda I-6,118 [Fray Alonso's text is organized through a traditional methodological design based on $d u$ das (doubts)]

67. ["en tal caso el rey o el emperador excederían la potestad que se les concedió, y si el pueblo reclamara o no lo consintiera, tal donación no valdría” 7 . Ibid., Duda I-8, pp. 121-122.

68. ["... aquellos que en estas partes tienen un pueblo, o entero o en parte, sin concesión de alguien, los tales poseen injustamente, cuando consta que es contra ta voluntad del propio pueblo y contra la voluntad del gobernador del pueblo al que lla-
Fray Alonso did not question the dominion of Emperor Carlos V over the new lands as being "just" (though he himself did not explain it and explicitly left the task to others). Rather, he contrasted the principles of the potestas populi and the derecho de retroversion (right of restoration) with the actions of the encomenderos who were receiving lands and the service of the Indians "in donation." This neither makes Fray Alonso's defense of those principles less passionate, nor his application of them to the situation in New Spain less clear and unequivocal. It should be noted that the restoration advocated by Fray Alonso was not made to the emperor, who granted the "donation," but to the original community, the Indians. Though this treatise was aimed at holding the encomenderos responsible for the illegitimate and tyrannical use of dominion, Fray Alonso was addressing such ambiguous issues that he almost touched on what, at that time, would undoubtedly have been considered high treason. The following example highlights the point: ". . the Emperor has no other dominion than the one conceded to him by the republic itself, so that, should his rule be tyrannical, the republic could depose him and deprive him of his kingdom. And the republic can contradict the donation made by the Emperor. Therefore, he to whom the donation was made does not receive by right those things that the Emperor also did not receive [by right]." 69 ?

The friars, just as later political theorists such as Milton or Locke, based their theoretical arguments on the contractual origin of political legitimacy, which was founded on the principle of the natural liberty of man. That view, staunchly defended by the Neo-Scholatics, was grounded in the theology of the Middle Ages, which had been taken up again in early sixteenth century by John Mair and his disciples, who, in turn, had been Vitoria's teachers at the University of Paris. However, Alonso de la vera Cruz and Bartolomé de las Casas took a radically new step. They both applied those principles not to their own native European populations but to the New World's indigenous communities. In otber words, they applied the radical theories, which would later provide

man cacique, y que los tales poseen por la fuerza y la violencia. (.. ); y a menos que restituyan, no pueden ser absueltosiy la restitución es debida a la comunidad misma

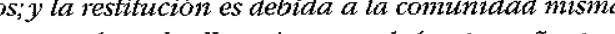
al señor de aquella comunidad, ya se ticular"]. Ibid., Duda I-38, pp.126-127.

69. [“. . el emperador no tiene otro dominio sino el que se le ba dado por la misma república, de tal suerte que si gobernara tiránicamente, podria la república deponerlo y privarlo del reino. Y la república contradice esta donación que se hace por el emperador Por tanto aquél a quien fue becha la donación, no recibe justamente las cosas perador por tanto, aquel a quien fue becha la donacion, no reche jus que no recibina e is already dealt with in Alfonso X's Siete Partidas (Partida II, Titulo XV, 4-5), although in this case, it is concerned with the unity of the king's lands and not, as Fray Alonso is, with the principle of the potestas populi 
ducted in accordance with the will of the citizens expressed and formulated in constitutional laws, customs and habits, and political decisions. Finally, Pérez de Mesa maintained that the legal system was the State's only safeguard and that the people were obligated to eliminate tyrannical or misleading laws. His text concluded with a series of pretyrannical or misleading laws. His text concluded wiom monarchical regimes to democratic ones. The "middle man" ought to play a major regimes to democratic one because he argued, "in the cities the middle men are the best." ${ }^{75}$ In addition, Perez de Mesa outlined the rules for a democratic education.

There is a significant difference between Pérez de Mesa and the NeoScholastics whose texts have been discussed. As Luciano Lureña states, he "was a scientist in the strict sense of the word: a mathematician and a cosmographer who brought scientific precision and mathematical objectivity to his interpretation of politics. His discussion of politics was also informed by his historical knowledge and his active participation in contemporary European political debates." ${ }^{76}$ Thus the cosmographer turned political theorist utilized the language of reason to design figures whed political theorist utized the of society that was not only desirable, but predictable according to physical laws. ${ }^{77}$ In other words, Pérez de Mesa's posture vis-à-vis science, politics, and society, placed him within the paradigm that today is labeled as "Modern".

75. ["en las ciudades los hombres medios son to mejor"]. Ibid., XXV. He adds: "And . mo onew in alderman or a duke, since nature is andertang and then it would be innot partial but rather equal to all in the distribution of natral gift. The justice and violence to forbid this son of a shoe repairman or a rustic, the doctrine that is granted to the son of the alderman or of the nobleman, since the former might stand out more eminent in virtues and thereby more convenient for the city and for the entire State. [" $Y$ ninguno negará que no puede el bijo del zapatero o del villano nacer con más claro entendimiento y mejor natural que el bijo del regidor y el duque, pues la natuclaro entendimiento y mejor natu raleza no es parcial sino comun e igual a todos en la distribucion de tos dones naturales. Luego injusticia y violencia sería probibirle a este bijo del zapatero o del villano la doctrina que se concede al bijo del regidor y del caballero, pudiendo aquét salir más eminente en virtudes y por eso más conveniente a la ciudad y a todo el Estado"], (I-50).

76. ["era un científico en el sentido estricto de la palabra: un matemático y un a la cosmografo, que le pa ciencias de la naturaleza y su objetividad matemaica, mor la bistoria y sobre todo por el equilibrio y flexibilidad que le imponía su aficion por la bistoria y sobre todo por el condicionante, vitalmente vivido y expresado, de su circunstancia europea" $]$. Ibid. LXI. There is no reference to Saint Thomas Aquinas in the text of Pérez de Mesa, who sup ports his work directly in Aristotles' Politics. Aristotle's analysis had been precisely the topic of his public lecture to obtain his degree in the Universidad de Alcala.

$$
\text { 77. vibid., XXXVI. }
$$

The outcome of Pérez de Mesa's efforts was a radical political treatise that creatively reconfigured a series of traditional ideas established through the course of centuries and placed them within the epistemological framework of the author's scientific background. His work was enriched not only by inherited notions and historical and textual knowledge, but also by the political debates and practices of the tumultuous Europe of his day. He lived in a world shaken by the expansionist thrust of the British and French monarchies, the religious wars that followed the rise of Protestantism, as well as-the generally overlooked-eruption of the Dutch Revolution and the formation of the first republican government of the Modern Era. During this period, Spain experienced a profound economic crisis that, along with an increase in absolutist, coercive tendencies, persuaded Pérez de Mesa to assume a very critical attitude toward the Spanish Monarchy. Although Politics and Reasons of State was too radical a text to be authorized for publication, ${ }^{78}$ what is important for this current article is the fact that it existed. The treatise was linked to and woven into an imaginaire that had been collectively constructed throughout the course of centuries. Moreover, it was written within the context of profound changes that were engulfing most of Europe. Pérez de Mesa's work demonstrates that the flexibility of imaginaires favored the creation of a collective reservoir of ideas that provided societies options in moments of crisis.

In order to understand the potential of these ideas to influence the political practices of societies, it is necessary to assume the perspective proposed in this article. Neither linear genealogies of thought, nor those of a single author-or two or three-can account for the emergence of great political paradigms-where theory and action, including violence, are intimately intertwined-that transcend the tradition in which the ideas are embedded. ${ }^{79}$ Ideas and political practices are not generated or transmitted solely by reading or direct communication. The written word and pragmatic actions are incorporated into the collective imaginaires via multiple, multifaceted means. ${ }^{80}$ As a result, ideas resurface and are implemented in different situations that, in turn, become part of multiplethreaded imaginaires.

78. The text was kept in Cardinal Gaspar de Borja's library and taken years later to the National Library in Madrid

79. As is the case, for instance, with historians who permanently and insistently refer to Suárez (or more recently, to Emmerich de Vatel), as the single source to explain enormously complex processes.

80. I think that it is not necessary to have read Freud, Lacan, Marx or Milton Friedman for their theories to form part of our imaginaires and to furnish our own elucidations with supporting tools-even when proposing counter arguments of those modes of thought. 
The radical corpus of ideas that this work has discussed appear and reappear in the political language of Spain and the Indies throughout the Modern Era-from the rebellion of the comuneros de Castilla, to the seventeenth-century uprising in Cataluña, and the diverse Creole and Indian rebellions in America during the eighteenth century. ${ }^{81}$ Similarly, despite the imposition of absolutism, the mixed forms of the potestas populi remained dormant in municipal practices and in certain aspects of corporate representation. ${ }^{82}$ As Jordana Dym has shown, the action of the municipios became a means of transmitting representative practices between the Antiguo Régimen and the new. The same phenonmenon occurred with the figure of the vecino studied by Marta Irurozqui and Tamar Herzog. ${ }^{83}$ In both cases, the fundamental principle was the potestas populi. For predemocratic conceptualizations to be reshaped into democratic onesunderstood here in the holistic, totalizing, and indivisible sense established by the Great Atlantic Revolutions-, it is necessary to recast the conceptual tools located in the collective imaginaire for use in a new context. Although premodern conceptions and the practices derived from them do not necessarily prefigure democratic ones, they can-with an emphasis on "can"-within certain contexts become relevant as well as viable.

What is certain is that the political language of the potestas populi, with its diverse nuances, would reappear in the thousands of documents, newspapers, pamphlets, sermons, and catechisms produced in the changed political environment that emerged in Spain and America following the occupation of the Peninsula by Napoleon's troops. ${ }^{84}$ In these

81. See José Antonio Maravall, Las Comunidades de Castilla.; Mónica Quijada, "Las dos tradiciones"; Xavier Gil, "Republican Politics in Early Modern Spain. The Castilian and the Catalana-Aragonese Tradition", in Martin Van Gelderen and Quentin Skinner (eds.), Republicanism: A Shared European Heritage: Republicanism and Constitutionalism in Early Modern Europe, vol, I (Cambridge: Cambridge Univesity Press, 2002), 263-288. Lia Q Q vista de Indias (2008), in press.

82. For mixed forms of sovereignty in the Hispanic world, see Federica Morelli: " $\mathrm{La}$ revolución en Quito: el camino hacia el gobierno mixto", Revista de Indias, LXII: 225, (2002), 335-356

83. Jordana Dym, From Sovereign Villages to National States. City, State and Federation in Central America, 1759-1839 (Albuquerque: University of New Mexico Press, 2006); Marta Irurozqui, "De cómo el vecino hizo al ciudadano en Charcas y de cómo el ciudadano conservó al vecino en Bolivia" in Jaime E. Rodríguez O. (coord.), Revolución, independencia y las nuevas naciones de América, 451-484. Tamar Herzog: "La vecindad: entre condición formal y negociación continua. Reflexiones en torno a las categorías sociales y las redes personales", Anuario del IEHS, 15, (2000), 123-31; Ibid.: Defining NaCinisen in Early Modern Spain and Spanish America (New tions. Immigrants and Citizens in

84. With regards to the usage in America of sermons and catechisms to diffuse the principles of the potestas populi, the retroversion of sovereignty and other founding no- and other documents, a variety of concepts systematically appeared that were associated with the recognition of the community as the only legitimate source of power. These ranged from the original contract between the people and the ruler to the rights of the individual; the different methods and timing of political renovation, including election; the welfare of the people as the unique aim of the transfer of sovereignty; the subjection to the law by both the rulers and the people as the basis of political and social organization; and the belief that citizenship required active participation. These were the notions that laid the foundations for the debates in Cádiz. They were also the basis for an extraordinary original act: an ample interpretation of the concepts of nation and citizenship that fully integrated the Indian population of the Spanish Monarchy. ${ }^{85}$ Indeed, even before the promulgation of the Constitution of 1812, Indians had been included in the electoral practices that spread throughout the Hispanic world following Napoleon's invasion and that were grounded on the principle of potestas populi as the only source of political legitimacy. 86

tions of political change, see Marta Irurozqui, "El sueño del ciudadano. Sermones y catecismos políticos en Charcas tardocolonial" in Mónica Quijada y Jesús Bustamante: Klites intelectuales y modelos colectivos. Mundo Ibérico (siglos XVI-XIX, (Madrid: Consejo Superior de Investigaciones Cientificas, 2002), 219-250. With regards to the propagation of the not-so-justly called "new" revolutionary ideas by the press and pamphiets, it is difficult to give the bibliography justice because of its extensive size. I will only cite a few texts considered particularly representative: María Teresa Berruezo León la lucha de Histenario, 1989); François-Xavier Guerra, Modernidad e independencias (Madrid: Mapfre, 1992); Ascensión Martínez Riaza, La prensa doctrinal en la independencia del Per, (Madtid: Enstituto de Cooperación Iberoamericana, 1985)

85. According to the Constitution of Cádiz: "sovereignty resides essentially in the Nation" ["la soberania reside esencialmente en la Nación"] (Art. 3), "the Spanish Nation is the union of all men born free and avecindados in the dominions of the Españas, and their sons" ["la Nación española es la reunión de todos los bombres libres nacidos y avecindados en los dominios de las Españas, y los bijos de estos"] (Art 1), and "they are citizens all those Spaniards that by both lines bring forth their origin in the Spanish dominions of both hemispheres, and who are avecindados in any town of the same dominions" ["son ciudadanos aquellos españoles que por ambas lineas traen su origen de tos dominios españoles de ambos bemisferios, $y$ estan aveindados en qualuuter puebto de los mismos dominios"]. Having "originated" in the "Spanish dominions in both hemispheres", all the Indians avecindados in them were incorporated not only in the "Spanish nation", but also in the more restrictive principle of "citizenry".

86. It is helpful to recall that following the subjection of the great pre-Hispanic empires, the Crown transferred its medieval-rooted and renaissance-reformed municipal model to the areas of nuclear population. The cabildo system facilitated the articulation of two levels of Indian leadership: the nobility, established through bloodline, and the politico-elective, exerted by the Indigenous cabildo and based on ethnic representation, which included the common Indians. See Francisco González-Hermosillo Adams (coord.), 
Among the developments of the thought processes that nourished he political imaginaires of the Hispanic world, one was extraordinary: the belief that the theories claiming popular sovereignty as the only lethe belief that the theories claild and ought to be applied to ican native populations. Here it is important to remember that they were concued populations who were incorporated into the structure of the clear-sometimes brutal-asymmetry. Spanish Crown in a siturion, it In order to understand the extratise historical exercise: The English suffices to conduct a small comparative historical exercise: The the sucCrown never recognized the Indians as subjects of the ktes, did not grant cessive governments of the new

hem citizenship until 1924.

Perhaps it is not completely coincidental that Bantolomé de las Casas,' De rege potestate, published in 1571 in Germany after being banned in Spain, was enthusiastically embraced published it in 1822 in Paris and in 1843 in Spain. The introduction of published it in 1822 in the treatise "could serve as a solid founthe latter edition stated that the treatise constitution of a modern re dation for the most splendid democratic constitution of a modern re public. . . . nothing [it went on to say] more liberal, more democratic, more essentially popular and equitable, nor more coercive in principle to the power of princes and rulers, has been written and established in to the power of princes 88

Are these ideas the only sources of the ample interpretation of naAre condiz? No. Do they form tion and citizenry found in the Constitution of Cadiz? No. Do they form part of a political imaginaire, created throughout the centuries, an in the inaire that contributed to defining the patterns of participation in ex-

Gobierno y economía en los pueblos indios del México colonia, (México: Instituto NaGional de Antropología e Historia, 2001); Claudia Guarisco, ktnicidad y ciudadania en México y Perú (1770-1850), (Lima: Documentos de Investigación, 84, 2004), scarlett México y Peru (1770-1850 O'Phelan Godoy, Kurakas sin sucesiones. Del cacique al alcinos Bartolomé de las Casas, livia 1750-1835 (Cusco:Centro de Estudios Regionales y Andinos Bartoloné de las Casas, 1997). For a historiographical general analysis see my work, La caja de Pandora. En tempopolítico indígena en la construcción del orden liberal," Revista de Historia Contempopoiftico indigena

87. Jaime E. Rodríguez O., "La naturaleza de la representación en Nueva España y (enero-abril 2005) $6-32$.

88. ["puede servir de sólido fundamento para la $m$ *s espléndida constitucion democr*ica de una moderna república... nada más tiberal, más democrático, más democi ma no poplar y equitativo, ni más coercitivo en principio de las facultades de esencialmente popurnantes se ba escrito y establecido en las constituciones modernas". los príncipes y gobernantes se ba escrito y establecido en las conste las Casas: De regia potesCited in $\mathrm{x}$. panding electoral practices associated with the adaptation and reconfiguration of the municipal tradition, and in shaping a constitution such as the one of Cádiz? Yes. I refer to this when I speak of the tapestrythe general pattern-and the diverse threads-the specificities-that allowed the various Western political and cultural traditions to become Modern. 